\title{
Factors impacting firm failure and technological development: A study of three emerging- economy firms
}

Solmaz Filiz Karabag

The self-archived postprint version of this journal article is available at Linköping University Institutional Repository (DiVA):

http:/ / urn.kb.se/ resolve?urn=urn:nbn:se:liu:diva- 146279

N.B.: When citing this work, cite the original publication.

Karabag, S. F., (2018), Factors impacting firm failure and technological development: A study of three emerging-economy firms, J ournal of Business Research.

https:// doi.org/ 10.1016/j.jbusres.2018.03.008

Original publication available at:

https:// doi.org/ 10.1016/j.jbusres.2018.03.008

Copyright: Elsevier

http:// www.elsevier.com/

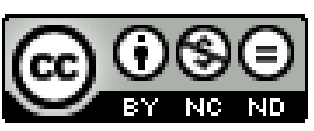




\title{
Factors impacting firm failure and technological development: A study of three emerging-economy firms
}

\author{
Solmaz Filiz Karabag \\ Department of Management and Engineering, Linköping University \\ 58183 Linköping, SWEDEN, sfkarabag@gmail.com Telephone: +46735807996
}

\begin{abstract}
Several studies examine the successful globalization and technological development of emergingeconomy firms. However, few discuss why some other emerging-economy firms do not develop sufficient technological capabilities, and thus, fail in domestics and global markets. Consequently, the understanding of emerging-economy firm diversity is limited. By analyzing the failure of three firms in two major industries in Turkey, this study identifies a complex set of factors contributing to this outcome. These factors include political risk, macroeconomic regime, national technology policies, and industry dynamics, as well as firm-related factors such as ownership, strategic intent, and the approach to, and current stage of, technology capability development. The results indicate that some of these factors support firm success in the short term but discourage learning and technological capability building, and thus, cause firm failures in the long term. Thus, the study illustrates the importance of studying emerging-economy firms from an extended contextual and temporal perspective.
\end{abstract}

Keywords: firm failure, technology development capability, business group, industry dynamics, emerging-economy firm, economic regime and volatility

Funding: This work was supported by VINNOVA, Sweden's national innovation agency (grant number: 2014-03388).

\section{Declarations of interest: none}

\section{Acknowledgements}

The idea of the paper was first discussed during the Second Emerging Markets Inspiration (EMI) Conference in Stockholm on June 8, 2017. The author is grateful to the organizer of EMI, Tony Fang, for the encouragement to develop this idea further. The author is also thankful for the helpful comments offered by Christian Berggren, two anonymous reviewers, and the guest editors, Joseph Amankwah-Amoah and Xiaojun Wang. This work was supported by VINNOVA, Sweden's national innovation agency (grant number: 2014-03388). 


\section{Factors impacting firm failure and technological development: A study of three emerging- economy firms}

\section{Introduction}

The international success of emerging-economy firms (EEFs), such as Embraer (Vértesy, 2017), Huawei (Fan, 2006), Hyundai Motor Co. (Kim, 1998), and Arçelik (Karabag \& Berggren, 2014a), as well as Indian pharmaceutical firms (Chittoor, Sarkar, Ray, \& Aulakh, 2009), has been the subject of many studies in the fields of development economics, management, and innovation. Some studies argue that the firms in these countries have been successful because of their national economic and institutional contexts (Jenson, Leith, Doyle, West, \& Miles, 2016). However, few discuss why some industries from the same emerging economies develop unique competitive advantages, while others do not (Hung \& Whittington, 2000). Moreover, existing studies seldom explain why some EEFs succeed, while others within the same industry fail. For example, Korea has developed internationally competitive capabilities in the automotive industry. However, it is not clear why Hyundai succeeded both in the national market and globally (Amsden, 1992), while Samsung Motors and Daewoo Automotive failed (cf. Hundt, 2014).

Studies of firm failures are dominated by findings from developed economies (Thornhill \& Amit, 2003). Studies of EEF failures have only recently emerged, and the majority of these predict organizational failure by using economic models and analyses (Amankwah-Amoah \& Zhang, 2015; Canbas, Cabuk, \& Kilic, 2005). Barring a few exceptions (Amankwah-Amoah, 2014), differentiated analyses of EEF failure are lacking. While existing studies highlight the fact that diversified business groups create competitive advantage, there is limited critical analysis of the ambiguity of this type of ownership and its role in causing EEFs' failures. Further, the role of firm strategies and technology development in relation to firm failure in emerging economies is insufficiently studied. Furthermore, existing studies tend to portray the political and economic 
context, including the role of state protection in emerging economies, as supportive of the development of competitive advantage. Few analyze how political and economic instability (e.g., sudden liberalization) and other contextual factors may also create disadvantages, hinder firm learning and capability development, and lead to firm failure. Finally, while existing studies acknowledge that EEFs have limited resources and capabilities, the rise and potential fall of their technological capabilities have only recently been recognized (cf. Amankwah-Amoah \& Durugbo, 2016).

This study aims to bridge these gaps in the literature by analyzing the impact of both external and internal factors in relation to firms' failures and truncated development in an emerging economy. To this end, three firms in the white-goods and automotive industries in Turkey are analyzed with a focus on their technology development capability and overall performance from inception to the time of exiting the market.

The study contributes to the existing literature on the failure of EEFs (Amankwah-Amoah, 2016) and their capability building in several ways. While most studies of EEF failures typically use statistical methods to predict firm failures, this qualitative study shows that the reasons for firm failure are complex. In particular, we identify three sets of factors: national (e.g., political instability, volatile economic context, and lack of relevant technology policies); industry dynamics (e.g., changes in competitive intensity, regulatory standards, and consumer demand); and firmrelated [e.g., ownership characteristics, strategy (intended and realized), technology management approaches, and stage of technology development]. Specifically, we show that the technological upgrading of EEFs from one stage to the next cannot be taken for granted, as implicitly assumed in influential studies (Bell \& Figueiredo, 2012; Hobday, 1995). The study shows that a firm may fail even if it moves to a more advanced capability stage; this is owing to a combination of internal 
and external factors. The findings also illustrate the problems of ascribing a generally positive and stabilizing ownership role to diversified business groups, which are common ownership types in emerging economies (Colpan \& Hikino, 2010). Moreover, the study suggests that some factors, such as the national economic and political regime, may lead to general success and firm learning in the short term, but limit learning and innovation capability building in the longer term.

The remainder of this paper is organized as follows. Section 2 reviews the literature on the factors that lead to firm failures. Section 3 describes the research methods used in this study. Section 4 summarizes the post-war history of the Turkish economy and the country's major political changes in order to describe the external environment of the analyzed firms. Section 5 presents detailed case analyses of three firms. The concluding section 6 discusses the factors that lead to firm failures and hinder learning and technological development; it also provides managerial implications, and limitations of this research, as well as suggestions for future studies.

\section{Theoretical framework: Factors impacting on organizational failure}

The central question in management studies-"Which key factors make some firms more successful than others"- has been researched extensively (Karabag \& Berggren, 2014b: 2212). However, this question cannot be fully understood without answering the related research question why some firms fail (Whetten, 1980). However, despite research over the past three decades (Amankwah-Amoah, 2016), there is little consensus on what firm failure is and the factors that cause it (Mellahi \& Wilkinson, 2004; Sheppard \& Chowdhury, 2005). Cameron, Sutton, and Whetten (1988: 8) define firm failure "as a deterioration in an organization's adaptation to its micro niche and the associated reduction of resources within the organization". Other researchers interpret firm failure as a discontinuance of the business or an exit from the industry (AmankwahAmoah, 2016). This study builds on both these definitions. 
To explain firm failures, the literature uses two main types of theoretical frameworks: deterministic and voluntaristic (Amankwah-Amoah, 2016; Mellahi \& Wilkinson, 2004). While the deterministic view assumes that managers have little or no control over their environment and that external factors determine firm failures, the voluntaristic view suggests that managerial decisions and strategic actions (i.e., internal factors) are the key causes of firm failures.

\subsection{Deterministic perspective}

The factors used in deterministic studies are rooted in industrial organization and ecology studies (Hager, Galaskiewicz, Bielefeld, \& Pins, 1996; Mellahi \& Wilkinson, 2004) as well as in theories of economic regimes and political risk, which are considered to be part of the overall institutional context (Luo \& Tung, 2007). Industrial organization scholars argue that firm performance is influenced by the industry structure and its dynamics, including such factors as changing customer demand, competitive intensity, and regulatory standards (Baum \& Singh, 1994; Porter, 1990). Moreover, innovations and new technologies create discontinuity in a firm's products and drive some firms out of the industry (Tushman \& Anderson, 1986). Based on this literature, the current research explores the role of industry dynamics in firm failure. Organization ecology theories provide complementary views on the role of the density of firms in a particular market and why high density may cause failures (Amankwah-Amoah, 2016; Hannan, 1997).

EEFs are also influenced by their country's economic regimes, which tend to differ from those in developed economies (Dornbusch, 1992). While developing countries protected their economies and restricted import of goods between the 1930s and the 1970s as a means of supporting local businesses, developed economies increasingly favored free trade regimes and open market policies (Finger, 1991). Owing to anti-statism, poor economic performance and pressure from the World 
Bank and IMF, many developing countries started to open up and liberalize their economies in the 1980s (Dornbusch, 1992). These liberalization policies increased their export performance and productivity, but also created macroeconomic instability, such as financial turbulence, liquidity shortages, balance of payments deficits, and unemployment (Erb, Harvey, \& Viskanta, 1996); all these may play significant roles in firm failures.

Further, a nation's institutions, such as its rules, regulations, universities and technological and R\&D infrastructure, determine firms' innovation capability building (cf. Jenson et al., 2016). Thus, national technology development policies can play a role in firm survival and capability building; however, not all firms have the same ability to benefit from those policies (Hung \& Whittington, 2000; Lee, 2013). Moreover, such policies evolve over time, and the resources allocated to the innovation system depend on domestic economic conditions and political preferences.

Not only are economic regimes and technology development policies different in emerging economies from those in developed countries. There is also a difference in terms of political (in)stability. Political instability "involves all non-business risks that have the potential to change the prospects of the profitability of a given investment" (Bastian \& Tucci, 2011: 2). The stability of political leadership, the presence of tensions (political, religious, ethnic, or regional), terrorism, and armed conflicts are indicators used to understand the political instability of a country (Erb et al., 1996). Empirical studies of political instability focus on the impact on FDI, tourism, household savings and consumption, and stock market behavior (Ksoll, Macchiavello, \& Morjaria, 2014). However, existing studies rarely explore the impact of political instability on EEFs' survival, investments, capability building, and entrepreneurship activities (Brück, Naude, \& Verwimp, 2013). 


\subsection{Voluntaristic perspective}

Whereas deterministic studies focus on external factors, research inspired by the voluntaristic view argues that firms can determine their future, including their failure, by their strategic decisions (Sheppard \& Chowdhury, 2005). Such internal factors include top management actions, the quality of human resources, the presence of distinctive capabilities, and the availability of financial capital (Amankwah-Amoah, 2014; Hambrick \& D’Aveni, 1992). Firms gain competitive advantage and survive by selecting a distinctive core strategy and developing their organization to implement this strategy (Porter, 1980). Hence, from this perspective, an EEF's strategy, intended and realized, is crucial. Empirical studies show that a firm's intended strategy might not be realized because of biases in managers' perceptions and decisions, conflicting intentions in the organization, unpredictable markets, and technological changes (Mintzberg \& Waters, 1985). In this study, intended strategy is specified as "a deliberate conscious set of guidelines that determines decisions into the future," while realized strategy is defined as "a pattern in a stream of decisions" (Mintzberg, 1978: 935).

Firm failure studies highlight that young firms are fragile and that the failure rate falls with increasing age (Levinthal, 1991). However, older firms that have developed strategic persistence may also fail in a changing industry and regulatory environment if they are unable to develop the relevant new technological and organizational capabilities. Several studies show that firm capabilities (i.e., competitive technologies; Fan, 2006; Kim, 1998; Vértesy, 2017; Tushman \& Anderson, 1986) and alignment with the external environment matter more than firm age (Thornhill \& Amit, 2003). Based on this literature, this study uses a firm's technology management approach as an indicator of its capability to align with the external environment. 
Researchers tend to explain the competitiveness and international expansion of EEFs by referring to their technology development stage. Hobday (1995), for example, suggests that EEFs follow specific stages when they develop their innovation capabilities. In the first stage, a firm learns assembly and basic production techniques. Next, the firm acquires product improvement and development skills. In the third stage, the firm designs products and conducts R\&D. In the final stage, the firm develops products and services for the global market (Hobday, 1995). Dutrenit (2000) argues that while these stages of technological development are essential, they are insufficient for long-term success; further, firms that do not develop the requisite organizational capabilities fail. Firm lifecycle models too imply that progression to advanced capability stages, although not straightforward, is important; otherwise, firms face the risk of stagnation and crisis (Amankwah-Amoah \& Debrah, 2014; Dutrenit, 2000; Sheppard \& Chowdhury, 2005) or truncated development. Thus, they become stuck at one technological development stage (Lall, 1992), and this increases the risk of failure.

An important difference between firms in emerging and developed economies is their type of ownership. In emerging economies, state-owned enterprises and diversified business groups have constituted the central forms of ownership. However, since the onset of economic liberalization, many emerging economies have privatized their state-owned enterprises and business groups have become the dominant ownership type (Colpan \& Hikino, 2010). Studies suggest a positive relation between business group ownership and firm success in Korea, India, Indonesia, Taiwan (Khanna \& Rivkin, 2001), as well as Turkey (Karabag \& Berggren, 2014b). According to these studies, business groups create not only financial resources for the member organizations, but also a platform for learning and knowledge sharing (Hsieh, Yeh, \& Chen, 2010). However, while 
entrepreneurship studies regularly highlight the role of the owner in a firm, studies of firm failure seldom consider ownership to be an important factor (cf. Amankwah-Amoah, 2014).

\subsection{Integrated perspective}

Several researchers, including Amankwah-Amoah (2016), Hager at al. (1996), and Mellahi and Wilkinson (2004), argue that deterministic and voluntaristic factors are interrelated and should be integrated, given that firm failure is not a sudden event and factors causing it can be dependent on each other. Such an integrated approach is important to explain the underlying mechanisms of failure (Hambrick \& D'Aveni, 1992). The literature on firm success and failure in established economies highlights that learning, technological, and organizational development capabilities are important mechanisms for long-term performance (Furr \& Kapoor, 2017; Hager et al., 2004; Thornhill \& Amit, 2003). Based on the foregoing discussion, the present study proposes an integrated framework that includes the four internal and four external factors described above to explore the drivers of EEF failure. In Figure 1, the negative values for these factors are related to insufficient learning and technology development capability, leading to firm failure.

\section{External factors \\ Political instability \\ Economic regime \\ National technology development policies Industry dynamics (competitive intensity, changing customer demand, and regulatory standards)}

\section{Internal factors}

Ownership (business group)

Strategy (intended and realized)

Firm technology management approach

Firm technology development stage

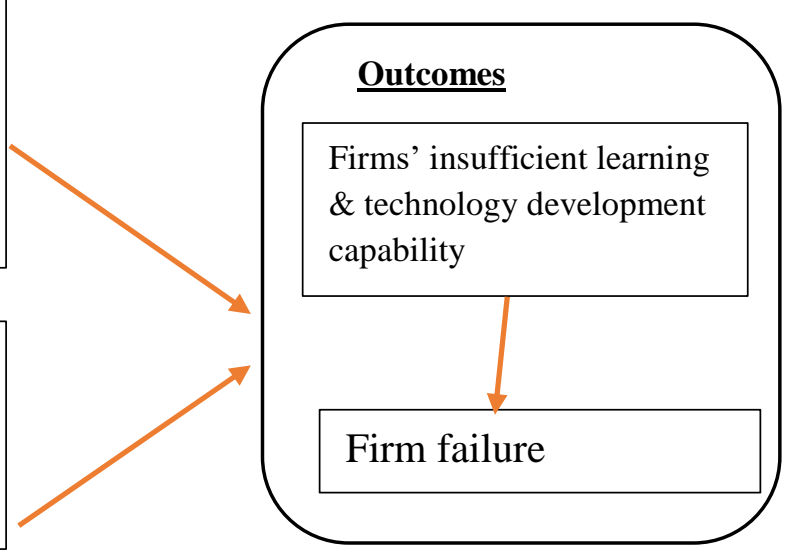

Firms' insufficient learning \& technology development capability

Firm failure

Figure 1. Integrated model of firm failure in emerging economies 


\section{Methods and data}

\subsection{Case selection}

This study examines the development of three Turkish firms (referred to as Firms A, B, and C herein) selected on purpose from two of the country's major industries: the automotive and whitegoods industries (Onwuegbuzie \& Leech, 2007). Some firms in these industries, such as Arçelik, an independent white-goods company, and Tofaş, an automotive joint venture (JV) with Fiat, have successfully developed their technology capabilities and now compete in the global market (Karabag \& Berggren, 2014a). However, several other Turkish firms in the same industries have been unable to develop the necessary capabilities and have been forced to change ownership or cease operations. This study analyzes three such firms. Table 1 presents basic information on the three case firms.

\section{Table 1. Overview of the firms studied}

\begin{tabular}{|c|c|c|c|}
\hline Features & Firm A* & Firm B** & Firm C*** \\
\hline \multicolumn{4}{|l|}{ General information } \\
\hline Analyzed years & 1960-1989 & 1996-2002 & 1966-2013 \\
\hline $\begin{array}{l}\text { Capacity per year } \\
\text { (last known) }\end{array}$ & $\begin{array}{l}15,000 \text { fridges and } \\
\text { washing machines in } \\
1979\end{array}$ & 17,000 light trucks in 2001 & 20,000 heavy vehicles in 2013 \\
\hline Brands & Kristal & Gold Light Truck & Alfa, Beta, Gamma, etc. \\
\hline Industry & White goods & Automotive & Automotive \\
\hline Target market & Turkey & $\begin{array}{l}\text { Turkey, Syria, Israel, and } \\
\text { Africa }\end{array}$ & $\begin{array}{l}\text { European, Asian, Central } \\
\text { American, and African countries } \\
\text { (around } 60 \text { countries) }\end{array}$ \\
\hline \multicolumn{4}{|c|}{ Ownership information } \\
\hline First owner & Evsan (1960-1969) & $\begin{array}{l}\text { Gold Holding, a business } \\
\text { group (1997-2002) }\end{array}$ & $\begin{array}{l}\text { Silver, the first business group } \\
\text { (1966-1989) }\end{array}$ \\
\hline Second owner & $\begin{array}{l}\text { Gold Holding, a business } \\
\text { group (1969-1984) }\end{array}$ & Russian investor (2002) & $\begin{array}{l}\text { Platinum, the second business } \\
\text { group (1989-2013) }\end{array}$ \\
\hline Third owner & $\begin{array}{l}\text { Owned by Gold Holding, } \\
\text { but rented to Firm X } \\
(1984-1989)\end{array}$ & NA & $\begin{array}{l}\text { Bronze, the third business group } \\
\text { (2013-present) }\end{array}$ \\
\hline $\begin{array}{l}\text { Presence of foreign } \\
\text { shareholders }\end{array}$ & No & No & $\begin{array}{l}\text { British (1966-1979) } \\
\text { Scandinavian (1983-1984) }\end{array}$ \\
\hline $\begin{array}{l}\text { Source: Author's dat } \\
* \text { Firm A exited the } \\
\text { group in } 2013 \text { becau } \\
\text { by the first and secol }\end{array}$ & $\begin{array}{l}\text { ection. } \\
\text { in 1989; ** Firm B } \\
\text { inancial difficulties. Th } \\
\text { iness groups. }\end{array}$ & $\begin{array}{l}\text { the industry in } 2002 ; * * * \\
\text { udy analyzes the factors af }\end{array}$ & $\begin{array}{l}\text { Irm } \mathrm{C} \text { was sold to a third business } \\
\text { ting Firm } \mathrm{C} \text { during ownership }\end{array}$ \\
\hline
\end{tabular}




\subsection{Data collection and analysis}

As firm failures are historical events, finding relevant and insightful data is quite difficult. Failures are also sensitive issues since the managers and owners who are involved could be seen as responsible for them (Froese \& Goeritz, 2007). To be able to ask potentially embarrassing questions and protect the interviewees' privacy, we avoided recording some of the interviews. Between April 2013 and June 2015, 8 respondents were interviewed in Adana, Bursa, and Istanbul in Turkey. For the first two cases, the principal owner and entrepreneur, as well as the sales manager (owner's daughter) shared their memories and provided relevant documents, such as product presentations and marketing plans. We supplemented their account by interviewing another local entrepreneur who traded with both these companies. In Firm C, we interviewed the previous R\&D manager (employed at this firm between 1971 and 2009) and an R\&D engineer (worked at Firm C in the 1998-2004 period). The failure of Firm C turned out be an embarrassing issue, which made it difficult to recruit more respondents. To reach data saturation, we also interviewed three R\&D managers from more successful white-goods and automotive firms. These interviews helped us understand the Turkish business culture and the variety of business group orientations, and the national technology policy. In addition to the failure interviews, we studied autobiographies and a history of the local white-goods and automotive industries (in Turkish), which provided the necessary historical perspective (cf. van de Ven, 1992). Where possible, the interview sources were complemented with data from product presentations, annual reports, industry documents, and company and academic publications (Ansal, 1990; Küçükerman, 2008).

The limited number of interviews in this study is comparable with other studies using qualitative research methods. Galvin (2015) argues that seven or eight interviews are common for explanatory studies, while Robinson (2014) suggests that three to sixteen interviews for each case 
can help reach data saturation. Several studies of sensitive and/or historical cases use fewer interviews than those in our study, since recruiting interviewees for such studies is challenging. For example, Matthews (2000) describes accounting history in the United Kingdom by interviewing one representative of the country's accountancy profession. Kroeze and Keulen (2013) also analyze four companies by selecting one interviewee from each.

In his accounting history study, Matthews (2000) states that the response of just one interviewee is not statistically valid; however, the importance and knowledge of the interviewee should be considered since he or she might be a major actor in the process. Some business history scholars suggest that it would be disadvantageous to use only one or a few informants (Hammond \& Sikka, 1996). On the other side, if scholars avoided research with small numbers of interviewees, they would have no data to relate the business to its past economic, social, and political contexts (cf. Kobrak \& Schneider, 2011). This approach would thus: lose the "silent knowledge and experiences" of actors who dominated and determined the present and future of the business (Giertz-Mårtenson, 2012: 113); overlook the lived experiences, thoughts, and reflections of individual actors (Maclean, Harvey, \& Stringfellow, 2017); and fail to value primary data. Although more respondents per case are desirable, full data saturation is seldom possible (O'Reilly \& Parker, 2013), and therefore, the eight interviews, complemented with other types of data, may be seen as a reasonable level of data collection in our study. Table 2 presents more information on the interviews. 
Table 2. Interview information

\begin{tabular}{|c|c|c|c|c|}
\hline Name & Firm & $\begin{array}{l}\text { Date of interview/ } \\
\text { mail }\end{array}$ & Location & $\begin{array}{l}\text { Length in } \\
\text { minutes/pages }\end{array}$ \\
\hline $\begin{array}{l}\text { Owner and CEO } \\
\text { (Gold Group) }\end{array}$ & Firm A and Firm B & $20 / 04 / 2013$ & Adana & 120 minutes \\
\hline $\begin{array}{l}\text { Sales Manager } \\
\text { (Daughter of the } \\
\text { business group owner) }\end{array}$ & Firm A and Firm B & $20 / 04 / 2013$ & Adana & 60 minutes \\
\hline An entrepreneur & $\begin{array}{l}\text { Did business with Firms A } \\
\text { and B }\end{array}$ & $22 / 04 / 2013$ & Adana & 70 minutes \\
\hline R\&D Manager & $\begin{array}{l}\text { Worked at Firm C during } \\
1971-2001 \text { and 2003-2009 } \\
\text { periods }\end{array}$ & $29 / 04 / 2015$ & NA & $\begin{array}{l}\text { 50-page document } \\
\text { that includes } \\
\text { answers to the } \\
\text { interview } \\
\text { questions }\end{array}$ \\
\hline R\&D Engineer & $\begin{array}{l}\text { Worked at Firm C between } \\
1998 \text { and } 2004\end{array}$ & $26 / 09 / 2014$ & Bursa & 70 \\
\hline \multicolumn{5}{|c|}{ The following interviews were used to gain complementary insights into Turkish innovation and the business context } \\
\hline $\begin{array}{l}\text { R\&D Manager } 2 \\
\text { (Arçelik) }\end{array}$ & $\begin{array}{l}\text { R\&D issues in the white- } \\
\text { goods industry } 1970-2000 \text {. } \\
\text { Working in the industry since } \\
1970 .\end{array}$ & $06 / 06 / 2015$ & Skype & 80 minutes \\
\hline $\begin{array}{l}\text { R\&D Manager } 3 \\
\text { (Arçelik) }\end{array}$ & $\begin{array}{l}\text { R\&D issues in the white- } \\
\text { goods industry } 1980-2005 . \\
\text { Working in the industry since } \\
1980 \text {. }\end{array}$ & $10 / 06 / 2015$ & Istanbul & 70 minutes \\
\hline $\begin{array}{l}\text { R\&D Manager } 1 \\
\text { (Tofaş) }\end{array}$ & $\begin{array}{l}\text { R\&D management and } \\
\text { development in the } \\
\text { automotive industry 1981- } \\
2009 . \\
\text { Working in the industry since } \\
1975 .\end{array}$ & $23 / 04 / 2014$ & Istanbul & 65 minutes \\
\hline
\end{tabular}

As shown in the following section, the individual case analyses are of different lengths because of three reasons. Firstly, the firms have different lifespans (Firm A's lifespan was 29 years; Firm B's was 6 years; and Firm C's was 47 years). Owing to its longer lifespan, Firm C was affected by more diverse economic, industrial, and other contextual factors than Firms A and B. Second, the firms studied had different levels and ambitions of technology development. While Firms A and B had no ambition to develop further technologies, Firm $\mathrm{C}$ wanted to advance its technological 
development capability ever since its establishment. Finally, Firm C had two international partners, which affected its operations and lengthened the case analysis.

\subsection{Informant bias}

The interviews helped us to understand the subjective experiences of the individuals who managed and tried to transform the case firms (Auerbach \& Silverstein, 2003). To reduce potential informant bias, we compared our interview data with information taken from industry publications, from managers of other firms in the same industry, and from entrepreneurs with knowledge of the relevant industries, regions, and firms. To analyze the data, we read and classified all interview comments related to the factors that contributed to the failure of the firms studied.

Before introducing the three cases, Section 4 reviews the development of Turkey's political and industrial context. A basic knowledge of this changing context from the 1960s to 2013 is important to understand the external factors affecting the studied firms and their performance. This context presentation is followed by the three case analyses of the firms and their technological development processes. Informative interview quotes are used to convey an authentic picture of these businesses' context, efforts, and uncertainties (Auerbach \& Silverstein, 2003).

\section{Turkey's economic and political environment, 1950-2013}

\subsection{Turkey's economic environment, 1960-1980}

In the 1950s, Turkey experienced a period of high economic growth. However, this led to an import boom and created an unsustainable deficit. To manage the deficit, the country introduced import substitution policies (Boratav, 2008), where import restrictions and high tariffs were 
complemented by direct investment incentives to new firms (e.g., subsidies and tax rebates) (Kazgan, 2004).

To support development and learning in strategic sectors, such as the automotive and whitegoods industries (Ansal, 1990), joint ventures (JVs) were formed with leading multinationals. While the foreign companies promised to transfer technological know-how, the Turkish partners provided investment capital, labor, and distribution systems (Erdoğdu, 1999). Owing to the import restrictions, low competition, and protective economic policies, returns on investment were high and several business groups accumulated great wealth (Bugra, 2008), which led to the creation of oligopolistic market structures (Zürcher, 2004).

However, while leading firms increased their market shares and profits, the development of technological capabilities languished (Kazgan, 2004). No policies were in place for developing parts and components industries, and the collaboration between local parts producers and JVs was non-existent (Ansal, 1990). The strategy of the JV's international partners was to provide old technologies and avoid investments in the technological development of the joint ventures (Erdoğdu, 1999).

During the 1970s, Turkey was not only endangered by high foreign exchange demand and national payment imbalances, but also dragged into political violence. This weakened the economy, and the resulting political instability exacerbated the negative impacts of the first oil crisis (Ansal, 1990; Duruiz, 1996). Crisis packages led to inflation and high external debt (Boratav, 2008), strikes and sit-ins (Zürcher, 2004), and ultimately a military intervention in September 1980. 


\subsection{Turkey's economic and political environment, 1980-1995}

In the 1980s, the military regime lifted Turkey's import restrictions (Kazgan, 2004) and sought to liberalize the economy to improve the global competitiveness of Turkish industries (Ansal, 1990). An export promotion regime was introduced using direct and indirect incentives; tariffs were reduced, especially on imports of intermediate and capital goods. Consumers increased their demand for manufactured goods such as cars, television sets, and fridges and the Turkish government invested heavily in infrastructure (highways, telecommunication). Consumers were "hungry for the technology, luxury, and modern life in general" and desirable European, Japanese, and US consumer goods became available (Zürcher, 2004: 308). Economic development, urbanization, and rural-urban migration expanded the market and increased product demand (Duruiz, 1996).

In this period, Turkish businesses discovered several export destinations, such as the Middle East, North Africa, and Europe. The collapse of the Soviet Union in 1990 opened up further export possibilities in Central Asia. The major export was textiles, and the tourism industry flourished. However, exports of automobiles and white goods were limited by their high production costs, low quality, outdated product technology, and obsolete manufacturing processes. These industries required large investments for the modernization of production, new products, and distribution and service networks in target markets (Ansal, 1990). Thus, Turkish firms experienced major difficulties in adapting to the new competitive domestic market and in entering competitors' markets (Erdoğdu, 1999).

From 1988, the Turkish economy began to suffer from rising fiscal and external imbalances (Demir, 2004). Although the government tried to support the exchange rate of the Turkish lira, the 
currency lost half of its value against the US dollar in early 1994, and the Turkish central bank exhausted 50\% of its reserves (Özatay, 2000). Interest rates skyrocketed (Celasun, 1998), leading the government to implement a stabilization program that involved a wage freeze, higher taxes, and reduced expenditure. As a result, gross national product "decreased by 6 per cent and more than 600,000 people lost their jobs" in 1994 and 1995 (Zürcher, 2004: 314). The production capacities of firms also fell sharply (Duruiz, 1996).

\subsection{Turkey's economic and political environment after 1995}

In 1995, Turkey signed a customs union agreement with the European Union (EU). This trade agreement required Turkey to implement the rules and regulations of the EU and accept the removal of tariffs and barriers for EU members (Pamukçu, Sekkat, \& Taymaz, 2010). Turkey’s imports and exports increased greatly after this agreement, as did the productivity of Turkish firms (Taymaz \& Yilmaz, 2014). However, the customs union agreement had ambiguous consequences for the domestic-oriented firms (Akbostancı, Tunç, \& Türüt-Aşık, 2011) and the competitiveness of Turkish firms remained lower than that of EU firms even several years after the agreement (Küçükahmetoğlu, Çeştepe, \& Tüylüoğlu, 2000). Moreover, Turkey did not address its macroeconomic problems, such as debt and inflation, and in 1998 the country suffered another sharp downturn (Yeldan, 2002; Zürcher, 2004). By entering into a standby agreement with the IMF in 1999, Turkey implemented an economic austerity program, which led to two years of financial turmoil and economic decline, including the collapse of several banks (Öniş \& Şenses, 2007). Approximately 600,000 businesses went bankrupt and around two million employees lost their jobs between 2000 and 2002 (Şenses, 2003). However, thanks to successful macroeconomic stabilization programs between 2002 and 2007, Turkey recovered and re-entered a period of high 
growth. Table 3 summarizes the critical economic and political events in Turkey between 1958

and 2013.

Table 3. Summary of the critical economic and political events in Turkey (1958-2013)

\begin{tabular}{ll}
\hline Year(s) & Event \\
\hline 1958 & Economic crisis and currency collapse \\
1960 & Political instability leading to the first political intervention by the military \\
$1965-1971$ & Political instability: conflict between the Islamist/right-wing and left-wing groups \\
$1960-1979$ & New economic regime: Import substitution and protection of national market \\
1971 & Political instability and military memorandum demanding that a new government \\
& be formed under democratic principles \\
$1975-1980$ & Violent right- and left-wing conflicts and new political instability \\
1978 & Balance of payments problems, currency devaluation, and economic crisis \\
1978 & IMF stability program \\
1974 & International political tensions and Turkish armed involvement in Cyprus \\
$1975-$ to date & PKK terrorism \\
1980 & Second political intervention by the military \\
$1980-$ to date & New economic regime: import quotas were substantially eliminated; the \\
& exchange rate was depreciated; and the foreign exchange regime was liberalized \\
$1982-1983$ & Financial market crisis, causing bankruptcy of financial brokers and small banks \\
$1984-$ to date & Reformed economic regime: liberalization of imports \\
$1988-1989$ & Stagflation and high inflation \\
1989 & Revised economic regime: full capital account liberalization \\
1991 & Economic crisis caused by the Gulf War \\
1994 & Economic and financial crises \\
1995 & Revised macroeconomic regime: market opening via the EU customs union \\
$1999-2001$ & Economic crisis: severe banking system losses and financial crisis
\end{tabular}

Sources: Author's data, collected through a survey of Turkey's economic history literature

\section{Case analyses}

\subsection{Case 1: Firm A, a white-goods firm}

Firm A was owned by Gold Holding (1940-2002), a diversified regional business group, in Adana, southeastern Turkey. The holding initially operated in the electronic wholesale and paper industries and later diversified into white-goods, construction, consultancy, banking, and automotive businesses. In its early years, an important unit of the group was a commercial distributor, Firm A, which sold radios, electrical items, and various apparatuses to businesses and 
households. The owner saw an opportunity to include white goods in his marketing network and acquired a firm in this industry. The owner explained:

At the beginning, there were only a few competitors where customers could buy these products. However, a new company, Evsan, was established by 10 engineers and managers who left Arçelik, one of the very first companies to produce fridges in Turkey. Firm A became one of Evsan's main distributors since demand for fridges was high. In 1969, Evsan had financial difficulties, and a bank took over its assets.

With an import tax rate around $280 \%$ in the 1960s (Zürcher, 2004), imports were very expensive. During this period, the most important components for white goods were electric motors and compressors. All Turkish white-goods companies had to buy such components from Türk Elektrik Endüstrisi (TEE), the leading domestic producer of electric motors and compressors in the 1960s and 1970s. As the owner of Firm A stated:

Since there was high demand from competitors, firms had to pay TEE in advance and wait for components for several weeks. Evsan got bank credits to pay TEE in advance but it was not able to pay its loan on time. To conduct such business, you can't rely on the bank. But Evsan did. When I heard Evsan was taken over by the bank, I went to Istanbul in 1969, saw its production equipment, and bought Evsan.

The owner of Firm A transferred both the production equipment and some of Evsan's managers and engineers from Istanbul to Adana. According to the owner, learning production was no problem, since the production technology was simple and machines and equipment easy to use. Although no license was required, building a new factory and configuring the equipment took two years. 
The protective Turkish import substitution regime helped the firm sustain its market position in the early 1970s. Firm A did not invest in new product development or acquire new technologies. It grew in parallel with the strong national economic growth (Aydas, Metin-Ozcan, \& Neyapti, 2005). The owner stated:

We had the economic power to make advance payments for components. In those years, the key factor was a strong distribution system, which we had with Firm A so we could access customers. The problem was that we could not find enough products to sell. There was a huge demand. Customers paid in advance and waited several months to get their products. We earned very good money.

Turkey's economy started to decline in 1975 when the oil crisis and ensuing inflation caused instability. This decline was further exacerbated by political violence (see Section 4). This violence affected people's lives and businesses, and Firm A's owner was no exception. The sales manager provided the following insight:

When the conflict increased at the end of the 1970s, we lost contact with our distribution centers in Ankara, Istanbul, and Izmir. During those politically tumultuous years, our firm suffered. In the countryside, products were burned during their deliveries. Militants were attacking transportation vehicles, and there were constant strikes. We did not want to continue with the risk of operating in the whole country.

Thus, political instability changed the owners and managers' risk attitudes. Instead of operating across Turkey, Firm A concentrated its business in specific regions. In 1984, the white-goods production equipment was rented to another company (named Firm X in this study), which had a 
core business in small home electronic products, such as vacuum cleaners. However, Firm $\mathrm{X}$ ceased its white-goods operations after five years. The owner explained:

So, at the end of 1979 we slowed production at Firm A and focused on construction in our region. This business was less risky and more profitable. In 1984, Firm X asked to rent our factory including the equipment, and this was very profitable for me.

The deal with Firm $\mathrm{X}$ took place when Turkey was changing its economic policy, replacing the previous import substitution policy with export promotion and import liberalization. This regime allowed foreign firms to enter the Turkish market, thereby radically increasing its competitive intensity (Ansal, 1990). Prices were still high, but consumers wanted the new technologies provided by the foreign firms (Erdoğdu, 1999). Even the Turkish market leader, Arçelik, had problems and started to consider investing in its own R\&D capability (Karabag \& Berggren, 2014a). Firm X was producing old products based on Firm A's old technology, which was unsuccessful in the new business environment. After the termination of the rental contract, the owner of Firm A, Gold Holding, did not restart white-goods production. In 1989, the obsolete production equipment was finally sold to an iron recycling company, signaling the end of Firm A. The owner elaborated:

After the Firm X affair, I understood that white-goods technology was changing. Our equipment was old and we couldn't produce new technology products. Consumers did not want to buy our products. New competitors from abroad were bringing new technology and products perceived as dynamic and modern. I understood that competition with Bosch was impossible; hence, I sold our equipment and machines to the recycling company. However, during those 
years, there were market opportunities in other sectors, which included exporting to Russia and other Central Asian countries. So, I started a new exporting company.

\subsection{Case 2: Firm B, an automotive firm}

After exiting the white-goods business and ceasing production at Firm A, Gold Holding started an export business and targeted Central Asian countries and Russia. During this period, the group further diversified by starting an offshore bank in Cyprus and a hotel business in Azerbaijan. Next, Gold Holding entered the automotive industry by establishing an assembly plant in 1996, called Firm B in this study. At first, Firm B assembled Tata products in Adana for a year. In 1997, the firm began assembling vans based on chasses and engines imported from China. These vans were sold in Turkey, as well as in Syria, Israel, and Azerbaijan. The owner highlighted how he sensed this business opportunity:

I observed that our exports of various goods to Central Asia started to weaken in 1995. During one of my visits to China, I saw their practical vans and thought they could be a good alternative to the Tata assembly. So, I fixed a meeting with the Chinese owner and asked how much it would cost to import the vans to Turkey. They said 3,000 US dollars. I saw that the production was easy. So, we requested a list of components and found alternative assemblers in Turkey. We imported the chasses and engines /for a much better price/from China, and they showed us how to assemble them. We did a little bit of reverse engineering too; including some product adjustments. We then sold each of them for 2,900 US dollars in Syria, Israel and Africa and made a good profit.

In the 1990s, the new economic policies in Turkey strongly favored the financial sector: "In the 1990s, an enormous and unsustainable network of some 80 private banks with no connection 
with the real economy emerged to take advantage of quick returns from public sector debt" (Yeldan, 2002: 7). As a consequence, many Turkish businesses engaged in banking (Kazgan, 2004). By the end of 2000, the number of banks had increased to 80 (Yeldan, 2002), one of which belonged to Gold Holding. However, at the same time, Turkey suffered from a ballooning balance of payments deficit (Demir, 2009), and the Turkish lira suddenly lost almost half of its value. The country's unsustainable financial and economic policy hit many businesses, and several banks collapsed since they had US-dollar-denominated loans. Gold Holding's bank was also affected by this banking crisis.

Gold Holding tried to obtain state support for its automotive business and avoid the loss of the group's banking business. To support the Turkish automotive industry in this new competitive environment, the government introduced an incentive scheme that required firms to fulfill several requirements, such as belonging to the National Automotive Association and having engines that complied with EU emissions standards. However, Firm B's products and features did not meet these requirements. The owner explained how production at Firm B ceased:

I had debts due to my financial business. To pay them, I tried to obtain state support and I also needed incentives to sustain my automotive company, Firm B. But the incentive scheme of the government prioritized large business groups that produced automobiles and complied with EU standards. The requirements were designed for them. We, the small-scale commercial vehicle producers from Adana and other regional centers, could not meet them. The company had problems with liquidity, so we couldn't save it.

Thus, in 2002, Gold Holding sold Firm B to a Russian investor, but the new investor never restarted production. 


\subsection{Case 3: Firm C, an automotive firm}

In 1966, Firm C was established by Silver, a diversified business group, to assemble trucks in

Izmir on the Turkish west coast, using licenses from a British company that also became a shareholder. On this basis, Firm C started to build several products, such as heavy trucks, light commercial vehicles, agricultural tractors, and engines. The production technologies were not advanced, but Firm C's strategy was to learn about technological development from its British partner. The R\&D manager explained its development strategy:

We wanted to produce the best technology in Turkey. So, we decided to invest in R\&D. Our objective was to shorten the time for technology capability development and increase productivity. The licensing and partnerships were the solutions. As part of this partnership strategy, we had a shareholder who was able to develop what we thought was the best technology of the day. We imported their engine and other powertrain and chassis technologies and adapted them to our products.

In the 1960s and 1970s, there were three British managers at Firm C. However, Firm C's managers had the autonomy to select their R\&D engineers (Ansal, 1990). In this early period, Turkish managers and engineers had engineering degrees from foreign institutions. Human resource training mostly comprised visiting the R\&D units of partners and suppliers. However, Firm $\mathrm{C}$ was inspired by its British partner and opened a training center. The interviewed manager highlighted the firm's recruitment and development capability:

We blended our international education and learning from the British partner at Firm $C$ and shaped the $R \& D$ activities. We analyzed our British partner's $R \& D$ department and gained knowledge about designs, tests, materials, and standards... We also used our commercial 
relations to visit leading producers of gearboxes, brakes, fuel systems, and clutches, and to learn about their $R \& D$ activities.

Although Turkey tried to attract international investors and protect its national manufacturers, it did not invest in public R\&D infrastructure, such as government test laboratories (Erdoğdu, 1999); and Firm C and other industry actors could not develop such a national infrastructure alone. Instead, Firm $\mathrm{C}$ invested in its own production technologies, which allowed the firm to use local suppliers and components. At first, $60 \%$ of its products were locally produced, and the rest imported from Britain. Later, the contribution of local suppliers increased to $85 \%$. Using $100 \%$ local components was not possible since there were no Turkish engine suppliers. While Firm C was able to develop its own products in the late 1970s, the British partner later failed to develop its engine technology and fell behind its competitors. Firm C's R\&D manager explained the problem:

In the second half of the 1970s, we saw that we could stand on our own feet. We had human resources who could develop our own products. We also observed our British partner's technical and organizational failures and tried to manage the design and production problems of its products. When we did this, we were criticized by them. I remember that their design manager reported that the "Turks have dared to implement their own design." We also developed design skills for the chassis and cabin. However, we were not strong in engine development, so we needed other partners.

The British partner experienced organizational and technical problems at home, and in the early 1980s, it was unable to continue its partnership with Firm C. To sustain its technology and product development, Firm C sought alternative sources for licensing engines. In 1983, Firm C 
partnered with a Scandinavian truck company to use this company's engines and the new partner acquired the British company's shares in Firm C. The following quote indicates that the Scandinavian partnership brought new technological capabilities to Firm C. Although the partnership produced a successful development and launch, the Scandinavian partner decided to leave in 1986.

We mixed our existing knowledge with the Scandinavians' knowledge. Thanks to that, we developed a new model, Alfa, in one year. This model was very successful, and we gained a great market share. However, the partner suddenly left us. We had to find an engine partner in the global market since there was no national engine producer. Still, I don't know why the Scandinavians left us!

After this dissolution, Firm $\mathrm{C}$ started to license engines from the American engine manufacturer Cummins; on this basis, it renewed its Alfa models and developed a new series, Beta models. These models were Firm C's first independently developed heavy trucks. The sales records show that both Alfa and Beta models improved several times and were sold in Turkey for more than 20 years. In the late 1980s, however, the Silver business group experienced financial problems and sold Firm C to another business group, called Platinum in this study. This group was founded in the 1920s and had operated in the textile and construction industries; it had also acquired two banks in the 1970s and 1980s. In the 1990s, the group entered the telecommunications and high-tech industries. At the end of the 1990s, the business group had more than 100 firms in different industries. The following quote highlights the new owner's ambition, Firm C's R\&D needs, and the decision-making processes: 
The new owner had the intention of making Firm $C$ global. I believed that we were going to invest in new products, production technology, labs, and human resources to synchronize our $R \& D$ investment and business strategy. We had the capability to design and develop products, but we lacked the investment needed to make us competitive, and we also needed a new international partner to develop our designs further.

With the backing of this new owner, Firm C's R\&D team prepared a plan to improve its light vehicles and found a European design firm to support this product development. The plan included sending R\&D teams to Europe for training and later develop the mechanical components in-house. The R\&D manager presented the plan to the board:

The European designer had made its tender, and top management started the negotiation. Later, they asked the European firm to add designs for heavy and other vehicles. The problem was that nobody considered how the finances would be covered. The European firm started to work on its designs in 1991. However, the group's top management was not ready to undertake those project investments.

Thus, these plans and designs were not implemented and after two years, Firm C dropped the idea of developing its light vehicles and decided to focus on heavy trucks; its models had been developed in the 1980s and needed upgrading.

I left the company in the middle of 1991. After two years, I was offered the same position again. The management of the business group had changed, and new board members were dynamic and progressive. They understood the role of the corporate plan. So, we started making the investment. The development of heavy vehicles was the new priority. The European firm helped us develop the 
cabin, and we were able to improve the designs. So, we developed our Gamma models. We invested in Computer Numerical Control for our assembly and production.

In the initial years under Platinum, the second business group, Firm C's R\&D managers were able to select their employees. However, in 1998, the owner centralized its human resources management (HRM) and began to evaluate the performance of Firm C's R\&D, production, purchasing, and quality control engineers as well as marketers according to a standard format without any differentiation. This HRM evaluation approach harmed the development of R\&D human resources:

The salary scheme did not allow us to decide the salaries of the $R \& D$ engineers, to differentiate them. We were not able to attract top talent and internationally educated $R \& D$ sources as we were doing before. Many of our R\&D engineers switched to our competitors.

Firm C continued to use collaboration opportunities to improve its R\&D skills in the 1990s and 2000s. There was no accreditation or certification center in Turkey, so the firm created opportunities for its managers and engineers to visit its suppliers' R\&D development centers and co-designers. Since Firm $\mathrm{C}$ had to adhere to the tests and standards of the global Vehicle Certification Authority in the UK, the IDIAD in Spain, and the TÛV in Germany, they used these tests and standards when visiting suppliers. Firm $\mathrm{C}$ also learned from and collaborated with the national R\&D center and Istanbul Technical University.

During this period, Firm C exported trucks to 60 countries. It had 17 distributors and opened manufacturing units in Africa and Asia. It became the only Turkish firm to sell licenses abroad in the 1990s and 2000s. However, this was not without problems. European emissions standards were introduced in the 1990s, which Turkey later adopted. This forced Turkish firms to adopt different 
product development strategies for different markets. The following quote displays how the emissions standards put Firm $\mathrm{C}$ in a disadvantageous position:

European emissions standards change regularly, and we had to implement those standards to sell in the EU. Turkey required Euro 1; the European market required Euro 3. We were not prepared to have Euro 3 engines and had to import the required powertrains and invest in Euro 3 technology. However,our local competitors in Turkey were able to use Euro 1 engines and lower their costs. We had to develop both old and new technologies. These things required adaptations and improvements; they increased our costs and coordination time and reduced our profit.

Firm C's business group owner, Platinum, grew during the 1990s, doubling its business portfolio. However, owing to its two banks, the business group was affected by the 2001 banking crisis. Because of its foreign and domestic debt, it had to sell some of its extremely profitable telecommunication companies and one of its banks. The group retained a few of its businesses, including Firm C. Firm C continued its R\&D efforts. However, in 2007, its managers felt that the owner was no longer supportive. In the following quote, the manager speculated why the group withdrew its support from Firm C's development:

In 2007, the business group stopped supporting product development. There might be two reasons for this. The business group did not have financial power. Alternatively, Firm C had too many projects. The top management began to cut investment. Anyhow, we started to get less support. I retired from Firm C in 2009. I heard that most of the $R \& D$ staff too left the firm.

Firm C lost most of its R\&D engineers in the following year and tried to survive on the basis of its old models until 2013. Owing to the financial problems of the business group's bank, the 
Savings Deposit Insurance Fund of Turkey sequestrated some of the Platinum business group firms including Firm C and sold them to a third business group in 2013.

\section{Discussion and conclusion}

The case studies in Section 5 show that several interrelated factors affect a firm's strategy and decisions regarding investments in technological capability and the firms' ultimate failures. In this study, we classified them as internal and external factors. Internal factors include a firm's ownership, strategy, approach to technology management and technology development stage. External factors include political (in)stability, economic regime, national technology policies, and industry dynamics, such as competitive intensity, regulatory standards, and consumer demand. This section discusses how these factors had an impact on firm failures. See Table 4 for a summary of these factors and their impact on the firms.

The role of ownership: The owners of the firms studied were diversified business groups. Business groups constitute an important economic factor in Turkey (Colpan \& Hikino, 2010) as they help member

firms to access external (e.g., governmental) resources (Bugra, 2008) and to gain contracts, and support their financial performance and capability development (Karabag \& Berggren, 2014a). The ownershiprelated findings in this study provide a less positive picture. Both Firm B under its first owner and Firm $\mathrm{C}$ under its first and second owners experienced severe problems due to their business groups' unrelated banking activities. Similar cases have been observed in other emerging countries. For example, after the 1998 crisis, Samsung declared the bankruptcy of Samsung Motors, which was then sold to Renault, and Daewoo was also forced to sell its automotive division because of the group's financial problems (Hundt, 2014). These experiences indicate that business groups in Korea too could create risks for member firms. Our findings concur with those of Khanna and Yafeh (2005), who suggest that Turkish 
business groups seldom initiate sustainable risk sharing. Under unstable economic conditions, the business group owners that diversified into the banking and financial sectors posed fatal risks for the firms studied.

The role of strategy: The case analyses show that Firms A and B had a low-cost approach and a profit-making strategy that discouraged firm learning and technological development activities. Firm C, by contrast, adopted a differentiation strategy. However, the findings show a gap between Firm C's intended strategy and its realized activities (i.e., intentions of being global versus unfocused R\&D management and insufficient investment). Moreover, there was a gap between top management decisions and the requirements for technology development, which highlights the importance of aligning top management and R\&D management when deciding on technological investment and future products (Zahra, Neubaum, \& Huse, 2000). Moreover, the HRM practices at Firm C did not fit the expectations and requirements of its technology development strategy, resulting in the firm's failure to retain key human resources in the R\&D division. Thus, the top management's intended strategy was not realized because of its decisions in other parts of the organization.

The role of a firm's technological management approach: While Firm A did not have any specific $R \& D$ engineers, its production technicians were able to implement minor product adaptations when needed. Firm B had three engineers who worked to obtain components from Turkish suppliers and reduce production costs. However, they did not attempt to improve products, which limited the firm's success (Maidique \& Zirger, 1985). Firm C had its own R\&D employees and used both its international partners and external resources to train them. In the early years, its R\&D department was autonomous, which enhanced its learning and technology development capability. However, in later years, R\&D lost its autonomy, and top management became the major decision maker on product development, which 
negatively affected Firm C's technology development capability. Moreover, the second owner did not make adequate investments in R\&D (Calantone, Di Benedetto, \& Devine, 1993).

Initially, Firm C licensed its technology from its first international partner, which supported its learning and technology development capability. However, when that partner experienced problems, Firm $\mathrm{C}$ also suffered. After losing this international partner, Firm $\mathrm{C}$ experienced difficulties in finding appropriate engines, which hindered further learning and capability development. Subsequently, Firm C engaged with a second international partner, but this partnership was suddenly discontinued by the latter. Whereas several authors emphasize the advantages of international partnerships (e.g., Leone \& Reichstein, 2012), this study suggests that technology transfer and licensing may support short-term learning opportunities and firm success; however, these are insufficient to develop technological capability in the long term and sustain a firm’s survival (Tsai \& Wang, 2007).

The role of the technological capability stage: Figure 2 shows the technology development stages of the three case firms. Firm A made slight improvements in its production processes and specialized in a certain product, while Firm B learned to successfully adapt and assemble simple products. For Firm B assembly was the basic strategy, and local components were adapted to reduce costs rather than to improve product quality or enhance learning. Moreover, neither firm reached the next stage of technological development. Moving from one stage to the next requires significant investments in learning (Karabag \& Berggren, 2017) and organization capabilities (Dutrenit, 2000), and these firms may have seen such investments as too risky and a potential waste of resources. Alternatively, they might not have been motivated by their competitors or did not have the know-how to develop these capabilities. Moreover, the existing R\&D infrastructure in Turkey was unsupportive. 
Firm $\mathrm{C}$ moved from the first and second stages to the third stage: designing and conducting $\mathrm{R} \& \mathrm{D}$ for its own products and entering regional and global markets (Hobday, 1995). The failure of this firm implies that the trajectories of EEFs are not straightforward and include significant risks (Dutrenit, 2000; Jenson et al., 2016). Although Firm $\mathrm{C}$ had a history of developing its own technology, it was unable to align its intended and realized strategies and to sustain its competitive position because of failures to find long-term international partners, benefit from the developing national innovation system in Turkey (Autio \& Thomas, 2014), and adapt to changes in international standards and regulatory environment.

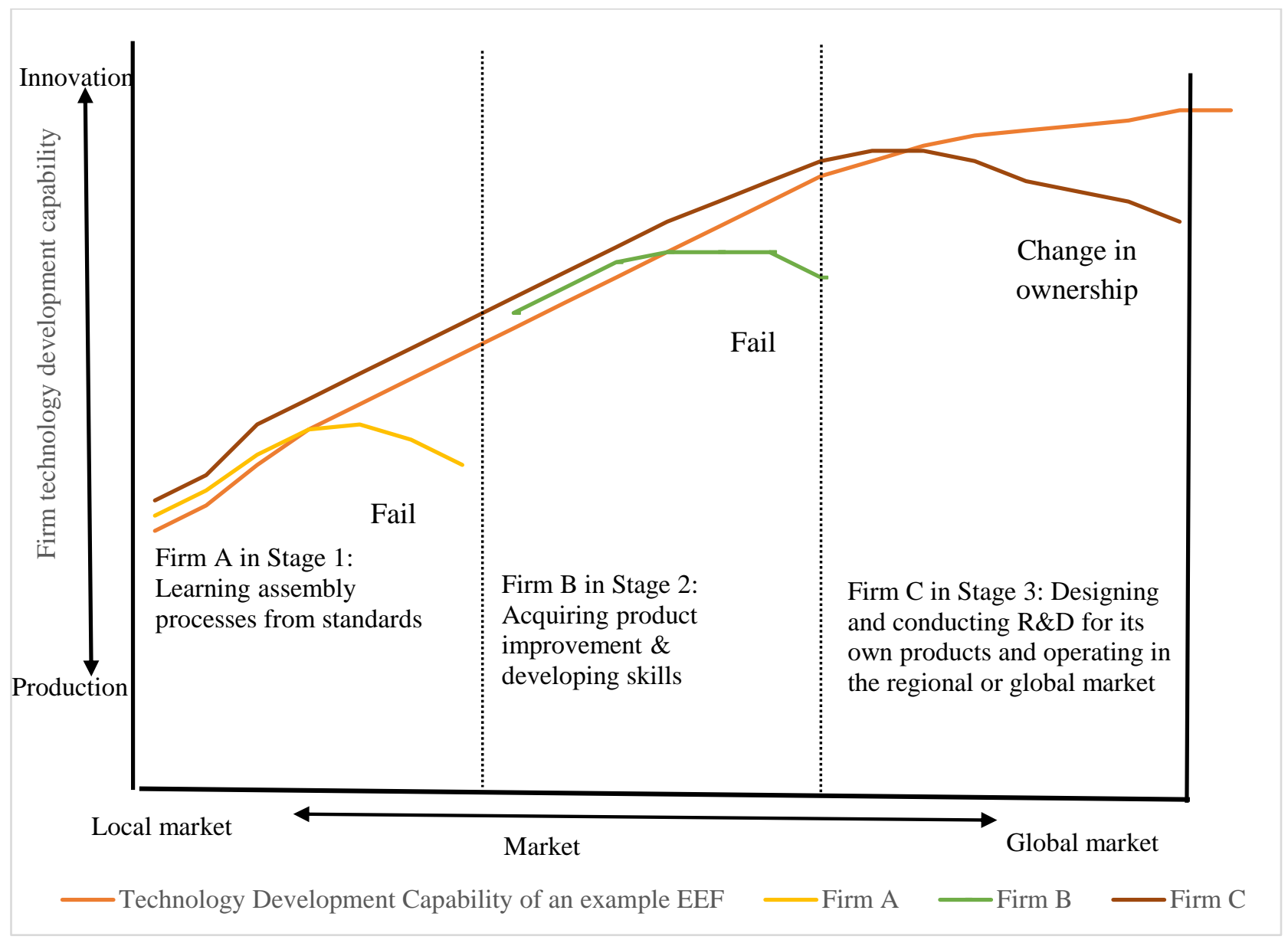

Figure 2. Technology development stages of the firms studied

Note: The figure is developed to visualize the stages of the firms' technology development. It uses qualitative, rather than quantitative data.

Source: author's data collection 
The role of the economic regime: The import substitution regime and protected market in Turkey until the mid-1970s supported firm learning of basic technologies. However, the very same economic regime discouraged firms from taking technological development to the next, international level. Therefore, it could be argued that import substitution hindered firms' ability to learn and develop new technologies in the long term and increased the risk of failures in the event of a change in the economic regime (cf. McGovern, 2007).

The findings from the case analyses support those in the literature that regime problems, such as currency volatility (Amankwah-Amoah \& Debrah, 2014), balance of payments problems, macroeconomic instability, and inflation, negatively affect firm survival (cf. Demir, 2009; Şenses, 2003), as well as hamper technological investment and development (Rafindadi \& Yusof, 2014). The ability to profit from the financial markets and exploit macroeconomic deficits fostered opportunistic behaviors and created barriers for the firms studied to invest in self-sustaining technology and innovate (Porter, 1990; Utterback \& Suarez, 1993). To succeed, firms need to adapt to changing market conditions and new rules of the economic game (cf. Hung \& Whittington, 2000). However, since economic patterns and rules shifted so quickly, firms faced recurrent adaptation difficulties. The Turkish economic regime changed drastically after 1980, inspired by Asian examples, such as Korea (Karabag \& Berggren, 2014b). A major difference, however, was the extent to which national firms were protected and supported. While the Korean government reduced intra-country competition and supported technological developments in business group firms until they joined the global competition (Amsden, 1992; Hobday, 1995), the Turkish government allowed firms from developed economies to compete directly with local firms in the national market (Erdoğdu, 1999; Karabag \& Berggren, 2014a). The negative impact of unplanned and unsupportive economic liberalization on firm survival was directly observed in the case studies. 
The role of national technology policy: Until the 1980s, Turkey's technology development policy was based on acquiring technology through an import substitution regime. This technology strategy allowed Firms A and C to learn basic production and assembly technology. However, demand for advanced products was not encouraged and, owing to high import costs, consumers had to accept old technologies. This national technology policy, therefore, helped these firms be profitable without investing in new product and process technologies and discouraged them from developing more advanced dynamic capabilities.

For example, the basic technologies used by Firms A and C were transferred to Turkey in the 1960s and had not been upgraded since then. Therefore, Turkish firms' products and production technologies were almost 20 years behind global technology in the 1980s. When Firm C struggled to cope with more stringent technology requirements after 1980, Turkish technology policies had yet to develop an appropriate innovation system that included governmental labs, test centers, and research institutes that could support firms' learning and survival.

Despite economic policy liberalization after the 1980s, it took many years for the state to develop a national technology infrastructure and R\&D culture (Pamukçu, 2003). Indeed, Turkey was able to develop its first formal national R\&D Act only in 2008 (BSTB, 2016). While some firms, such as Firm A, did not attempt to develop new technologies, others such as Firm B tried and achieved a certain level of local adaptation. Firm C invested in its own R\&D and operated globally (Ansal, 1990). However, its $R \& D$ could not use a suitable national $R \& D$ infrastructure to develop its skills further, which turned out to be fatal for its future. This study, therefore, complements previous work by identifying a gap between advancing firms' technology management and the national support and standards system, which may be of crucial importance when regulatory stringency increases in international markets. Such a mismatch 
may result in extra costs, lost time in product development, and futile struggles to meet advanced market requirements.

The role of political instability: The political instability and turmoil in Turkey during the 1970s negatively affected the studied cases and similar firms' sales, products, and entrepreneurial activities (cf. Ansal, 1990). Political instability made Turkey an unfavorable market for long-term business activities and hampered risk taking by its entrepreneurs. To reduce the risk of operating nationwide and manage environmental uncertainty, the owner of Firm A reduced production, temporarily rented its equipment to another company, and reallocated his entrepreneurial activities from the white-goods to the construction industry (cf. Desai, Acs, \& Weitzel, 2013). Moreover, while Firm C survived, this difficult period continued to have a negative effect (Ansal, 1990). Political instability has been identified as an important factor behind multinational firms' entry and exit strategies (Bastian \& Tucci, 2011; Desai et al., 2013), but should also be studied to understand the investment decisions, entrepreneurship activities, and failures of local EEFs.

The role of industry dynamics: While some studies argue that industry dynamics, especially competition, increases firms' technological and innovation capability (Galdon-Sanchez \& Schmitz, 2002), others state that the impact might be negative for infant firms and industries (Aitken \& Harrison, 1999). In the present study, increased competition did not contribute to the technological development of the investigated firms. One firm exited its market and another struggled both nationally and internationally. 
Table 4. Summary of factors that had an impact on the firms studied ${ }^{1, *}$

\begin{tabular}{|c|c|c|c|}
\hline Factors & Firm A & Firm B & Firm C \\
\hline \multicolumn{4}{|l|}{ External } \\
\hline \multicolumn{4}{|l|}{ Economic regime } \\
\hline Protected and instabilities (1960-1980) & $\begin{array}{l}\text { Positive in the early years; } \\
\text { negative in the long term }\end{array}$ & & $\begin{array}{l}\text { Positive in the early years; } \\
\text { negative in the long term }\end{array}$ \\
\hline $\begin{array}{l}\text { Liberalization and instabilities (1981- } \\
\text { 1995) }\end{array}$ & Negative & & Negative \\
\hline $\begin{array}{l}\text { Customs union membership and } \\
\text { instabilities (1996-2013) }\end{array}$ & & Negative & Negative \\
\hline \multicolumn{4}{|l|}{ Political instability } \\
\hline $\begin{array}{l}\text { Right- and left-wing conflicts (1975- } \\
1980)\end{array}$ & Negative & & Negative \\
\hline \multicolumn{4}{|l|}{ National technology development policy } \\
\hline Technology transfer policy $(1960-1995)$ & Negative & & Negative \\
\hline Limited national R\&D policy (after 1995) & & Negative & Negative \\
\hline \multicolumn{4}{|l|}{ Industry dynamics } \\
\hline \multicolumn{4}{|l|}{ Competitive intensity } \\
\hline (1960-1980): low & Positive & & Positive \\
\hline (1981-1995): high & Negative & & Negative \\
\hline (1996-2013): high & & & Negative \\
\hline \multicolumn{4}{|l|}{ Changing customer demand } \\
\hline (1960-1980): low & Positive & & Positive \\
\hline (1981-1995): high & Negative & & Negative \\
\hline (1996-2013): high & & Partly positive & Negative \\
\hline \multicolumn{4}{|l|}{ Regulatory standards } \\
\hline (1960-1980): simple & & & Positive \\
\hline (1981-1995): multiple and complex & & & Negative \\
\hline (1996-2013): multiple and complex & & Negative & Negative \\
\hline \multicolumn{4}{|l|}{ Internal } \\
\hline \multicolumn{4}{|l|}{ Ownership } \\
\hline \multirow[t]{2}{*}{ First owner } & Evsan: Negative & Gold Holding: & Silver business group: \\
\hline & & $\begin{array}{l}\text { Positive in the early } \\
\text { years; negative in the } \\
\text { long term }\end{array}$ & $\begin{array}{l}\text { Positive in the early years; } \\
\text { negative in the long term }\end{array}$ \\
\hline \multirow[t]{2}{*}{ Second owner } & Gold Holding: & Failed & Platinum business group: \\
\hline & $\begin{array}{l}\text { Positive in the early years; } \\
\text { negative in the long term }\end{array}$ & & $\begin{array}{l}\text { Positive in the early years; } \\
\text { negative in the long term }\end{array}$ \\
\hline \multicolumn{4}{|l|}{ Strategy } \\
\hline Intended & (Low cost/profitmaking) & (Low cost/profitmaking) & Differentiation \\
\hline Realized & (Low cost/profitmaking) & (Low cost/profitmaking) & Unfocused \\
\hline Strategic alignment & & & (Misalignment) Negative \\
\hline Technology management approaches & $\begin{array}{l}\text { Positive in the early years; } \\
\text { negative in the long term }\end{array}$ & Positive in the early years & $\begin{array}{l}\text { Positive in the early years; } \\
\text { negative in the long term }\end{array}$ \\
\hline \multirow{2}{*}{ Technology development stage } & Stage 1: & Stage 2: & Stage 3: \\
\hline & $\begin{array}{l}\text { Positive in the early years; } \\
\text { negative in the long term }\end{array}$ & $\begin{array}{l}\text { Positive in the early } \\
\text { years; negative in the } \\
\text { long term }\end{array}$ & $\begin{array}{l}\text { Coordination and management } \\
\text { problem in the long term }\end{array}$ \\
\hline $\begin{array}{l}\text { (In)sufficient learning and technology } \\
\text { development capability }\end{array}$ & Negative & & Negative \\
\hline
\end{tabular}

\footnotetext{
${ }^{1}$ (when available); *Success (positive)/ failure (negative); Source: Author's data collection.
} 
In the study, we also observed the impact of changing customer demand on the firms studied and their technological development. Firm B enjoyed a growing market both in Turkey and in other emerging economies, while Firm A's and Firm C's products had high local demand until the 1980s. When the Turkish market opened up, however, customers demanded more advanced designs and products. Firm A was unable to provide such new products, and thus, the changing demand in the 1980s contributed to its failure. Firm C struggled to keep up with the competition and started to export both to emerging and to established markets. However, different product standards and regulations limited its international success. This supports the proposition of Yamakawa, Peng, and Deeds (2008) that differences in the regulatory environments of emerging and established economies might be hard to manage for internationalizing EEFs.

\subsection{Managerial implication}

The findings suggest that internal as well as external factors influenced the firms studied, as well as their technology development capabilities and final failures. The results have implications for managers and policymakers both in Turkey and in other emerging economies, such as Argentina, Brazil, Chile, and India, which have experienced intense political tensions and changes in their economic regimes. Ownership by a diversified business group, which is common in emerging economies, initially supported the studied firm but later created serious problems when the business groups' financial investments failed and negatively affected all member firms. Moreover, the groups' diversification strategies were limited to the home market, with its uncertainties and unpredictable economic and political instability. To reduce this home country risk, business group managers are advised to expand actively into international markets and build the requisite capabilities for doing so. 
Another managerial implication is related to technological licensing and knowledge transfers from international partners. EEFs start with limited technological capabilities and there are few alternatives to technology licensing and other forms of international linkages (e.g., manufacturing contracts or joint ventures with multinationals). Such links may be crucial sources for firms' initial learning and technological development. However, owners should recognize that being dependent on international partners for future products and technologies may lead to truncated development, as also observed in the joint ventures in the Chinese automobile industry (Nam, 2015). The consequences could be serious if multinationals discontinue partnerships for reasons unrelated to the local context, as was the case for Firm C and its Scandinavian partner. Therefore, firms need to complement licensing with independent investment in their own learning and capability development.

In Turkey, strong economic growth initiated firm successes; however, later economic instability and crises contributed to firm failures. Other contextual factors, such as national technology policies and changing customer demand also contributed to this outcome. Industry dynamics in the form of regulatory changes may create both opportunities and threats. In the white-goods industry, global standards related to the ozone layer, and embodied in the Montreal Protocol, created an international window of opportunity for the Turkish white-goods pioneer Arçelik (Karabag \& Berggren, 2014a). By contrast, the increase in Europe's regulatory stringency concerning heavy vehicle emissions created serious problems for Firm C, which was already lacking in-house engine development capabilities and would have needed comprehensive state support to catch up with its competitors.

Economic policymakers in emerging economies should consider gradual approaches to market liberalization to allow national firms to learn and eventually become global competitors (Hobday, 1995). As highlighted in this study, economic crises may cause serious instability in emerging economies, encourage opportunistic financial behavior, and discourage firms from operating in technological 
industries that require long-term investment. While such crises may be difficult to avoid, it is recommended that policymakers and company managers invest in institution building to stabilize markets and mitigate risk in times of increased economic uncertainty.

\subsection{Limitations and directions for future research}

This study analyzed how complex internal and external factors limit firms' technological development and may lead to failure in the long term. The first limitation of the study stems from its focus on two industries in Turkey. Future studies of other EEFs should aim to deepen our understanding by analyzing a larger sample of firms from other industries and emerging economies. Future studies could also explore whether different industry-related factors affect firm failure. Second, we used data from interviews and secondary sources. Conducting a small number of interviews in each firm is an obvious limitation of this study. Further, the collected data did not allow us to clearly disentangle the negative impact of political instability from the impact of economic uncertainty. This study considered firm learning and technology development capability as underlying mechanisms. Future studies could quantitatively test whether these mechanisms are moderated by other external and internal factors.

\section{References}

Aitken, B.J., \& Harrison, A.E. (1999). Do domestic firms benefit from direct foreign investment? Evidence from Venezuela. American Economic Review, 89(3), 605-618.

Akbostanc1, E., Tunç, G.İ., \& Türüt-Aşık, S. (2011). CO 2 emissions of Turkish manufacturing industry: a decomposition analysis. Applied Energy, 88(6), 2273-2278.

Amankwah-Amoah, J. (2016). An integrative process model of organizational failure. Journal of Business Research, 69(9), 3388-3397.

Amankwah-Amoah, J. (2014). Old habits die hard: A tale of two failed companies and unwanted inheritance. Journal of Business Research, 67(9), 1894-1903.

Amankwah-Amoah, J., \& Debrah, Y.A. (2014). Air Afrique: the demise of a continental icon. Business History, 56(4), 517-546. 
Amankwah-Amoah, J., \& Durugbo, C. (2016). The rise and fall of technology companies: The evolutional phase model of ST-Ericsson's dissolution. Technological Forecasting and Social Change, 102, 21-33.

Amankwah-Amoah, J., \& Zhang, H. (2015). Business failure research: a review of the Chinese experience. International Journal of Foresight and Innovation Policy, 10(2-4), 180-197.

Amsden, A.H. (1992). Asia's Next Giant: South Korea and Late Industrialization. New York: OUP.

Ansal, H.K. (1990). Technical change and industrial policy: the case of truck manufacturing in Turkey. World Development, 18(11), 1513-1528.

Auerbach, C., \& Silverstein, L.B. (2003). Qualitative Data: An Introduction to Coding and Analysis. New York: NYU Press.

Autio, E., \& Thomas, L. (2014). Innovation ecosystems: Implications for Innovation Management, In M. Dodgson, D.M. Gann, \& N. Phillips (Eds.), The Oxford Handbook of Innovation Management (pp. 204-288). New York: OUP.

Aydas, O.T., Metin-Ozcan, K., \& Neyapti, B. (2005). Determinants of workers' remittances: the case of Turkey. Emerging Markets Finance and Trade, 41(3), 53-69.

Bastian, B., \& Tucci, C.L. (2011) Political risk and technology strategy: An empirical investigation. Presented at the Wharton Technology Conference, Philadelphia, PA, http://mackinstitute.wharton.upenn.edu/wp-content/uploads/2012/12/BastianTucci_Political-risk-andtechnology-strategy-An-empirical-investigation.pdf Accessed 1 March 2018.

Baum, J.A., \& Singh, J.V. (1994). Organizational niches and the dynamics of organizational mortality. American Journal of Sociology, 100, 346-380.

Bell, M., \& Figueiredo, P.N. (2012). Building innovative capabilities in latecomer emerging market firms: some key issues. In E. Amann, \& J. Cantwell (Eds.), Innovative firms in emerging market countries (pp. 24-109). New York: OUP.

Boratav, K. (2008). History of Turkish economy: 1908-2007 (in Turkish) (10th ed.). Istanbul: Imge Books.

Brück, T., Naudé, W., \& Verwimp, P. (2013). Business under fire: Entrepreneurship and violent conflict in developing countries. Journal of Conflict Resolution, 57(1), 3-19.

BSTB (2016). Private sector R\&D and Design Centers: A Manuel (in Turkish), The Ministry of Science, Industry and Technology. Ankara: BSTB publication.

Bugra, A. (2008). State and Business in Modern Turkey (in Turkish). Istanbul: İletişim Yay. 
Calantone, R.J., Di Benedetto, C.A., \& Divine, R. (1993). Organisational, technical and marketing antecedents for successful new product development. R\&D Management, 23(4), 337-351.

Cameron, K. S., Sutton, R. I., \& Whetten, D.A. (1988). Readings in Organizational Decline. Cambridge: Ballinger Pub.

Canbas, S., Cabuk, A., \& Kilic, S.B. (2005). Prediction of commercial bank failure via multivariate statistical analysis of financial structures: The Turkish case. European Journal of Operational Research, 166, 528-546.

Celasun, O. (1998). The 1994 currency crisis in Turkey (No. 1913). World Bank, Development Research Group. http://documents.worldbank.org/curated/en/965221468777258191/pdf/multipage.pdf Accessed 1 March 2018.

Chittoor, R., Sarkar, M.B., Ray, S., \& Aulakh, P.S. (2009). Third-world copycats to emerging multinationals: Institutional changes and organizational transformation in the Indian pharmaceutical, Organization Science, 20(1), 187-205.

Colpan, A.M., \& Hikino, T. (2010). Foundations of business groups: towards an integrated framework. In A. M. Colpan, T. Hikino, \& J. R. Lincoln (Eds.), The Oxford Handbook of Business Groups (pp. 15-66). New York: OUP.

Demir, F. (2004). A failure story: Politics and financial liberalization in Turkey, revisiting the revolving door hypothesis. World Development, 32(5), 851-869.

Demir, F. (2009). Financial liberalization, private investment, and portfolio choice: Financialization of real sectors in emerging markets. Journal of Development Economics, 88(2), 314-324.

Desai, S., Acs, Z.J., \& Weitzel, U. (2013). A model of destructive entrepreneurship: Insight for conflict and post conflict recovery. Journal of Conflict Resolution, 57(1), 20-40.

Dornbusch, R. (1992). The case for trade liberalization in developing countries. The Journal of Economic Perspectives, 6(1), 69-85.

Duruiz, L. (1996). Getting organized for customs union transformation efforts of Turkish automobile industry for the global markets. In the proceeding of the Fourth GERPISA international colloquium, (pp. 19-21), Paris. http://gerpisa.org/ancien-gerpisa/actes/18/article1.html-2.html Accessed 1 March 2018.

Dutrenit, G. (2000). Learning and Knowledge Management in the Firm: From Knowledge Accumulation to Strategic Capabilities. Cheltenham: Edward Elgar.

Erb, C.B., Harvey, C.R., \& Viskanta, T.E. (1996). Political risk, economic risk, and financial risk. Financial Analysts Journal, 52(6), 29-46. 
Erdoğdu, M.M. (1999). The Turkish and South Korean Automobile Industries and the Role of the State in Their Development, METU Studies in Development, 26(1), 25-73.

Fan, P. (2006). Catching up through developing innovation capability: evidence from China's telecomequipment industry. Technovation, 26(3), 359-368.

Finger, M. (1991). Development Economics and the General Agreement on Tariffs and Trade. In J. De Melo, \& A. Sapir (Eds.), Trade Theory and Economic Reform: North, South, and East (pp. 203-233). Cambridge: Blackwell.

Froese, F.J., \& Goeritz, L.E. (2007). Integration management of Western acquisitions in Japan. Asian Business \& Management, 6(1), 95-114.

Furr, N., \& Kapoor, R. (2017). Capabilities, technologies, and firm exit during industry shakeout: Evidence from the global solar photovoltaic industry. Strategic Management Journal, 39(1), 33-61

Galdon-Sanchez, J.E., \& Schmitz, J.A. (2002). Competitive Pressure and Labor Productivity: World Iron-Ore Markets in the 1980's. The American Economic Review, 92(4), 1222-1235.

Galvin, R. (2015). How many interviews are enough? Do qualitative interviews in building energy consumption research produce reliable knowledge?. Journal of Building Engineering, 1, 2-12.

Giertz-Mårtenson, I. (2012). H\&M-documenting the story of one of the world's largest fashion retailers. Business history, 54(1), 108-115.

Hager, M.A., Galaskiewicz, J., Bielefeld, W., \& Pins, J.J. (1996). Tales from the grave: Organizations' accounts of their own demise. American Behavioral Scientist, 39(8), 975-994.

Hambrick, D.C., \& D'Aveni, R.A. (1992). Top team deterioration as part of the downward spiral of large corporate bankruptcies. Management Science, 38(10), 1445-1466.

Hammond, T., \& Sikka, P. (1996). Radicalizing accounting history: the potential of oral history. Accounting, Auditing \& Accountability Journal, 9(3), 79-97.

Hannan, T.H. (1997.) Market share inequality, the number of competitors, and the HHI: An examination of bank pricing. Review of Industrial Organization, 12(1), 23-35.

Hobday, M. (1995). East Asian latecomer firms: learning the technology of electronics. World Development, 23(7), 1171-1193.

Hsieh, T.J., Yeh, R.S., \& Chen, Y.J. (2010). Business group characteristics and affiliated firm innovation: The case of Taiwan. Industrial Marketing Management, 39(4), 560-570.

Hundt, D. (2014). Economic crisis in Korea and the degraded developmental state. Australian Journal of International Affairs, 68(5), 499-514. 
Hung, S.C., \& Whittington, R. (2000). Playing by the rules: institutional foundations of success and failure in the Taiwanese IT industry. Journal of Business Research, 47(1), 47-53.

Jenson, I., Leith, P., Doyle, R., West, J., \& Miles, M.P. (2016). Innovation system problems: Causal configurations of innovation failure. Journal of Business Research, 69(11), 5408-5412.

Karabag, S. F., \& Berggren, C. (2017). Struggling with knowledge boundaries and stickiness: Case studies of innovating firms in an emerging economy. In F. Tell, C. Berggren, S. Brusoni, \& A. Van de Ven (Eds.), Managing Knowledge Integration across Boundaries. (pp. 139-154). Oxford: OUP.

Karabag, S.F., \& Berggren, C. (2014a). Joint ventures or independence? Alternative ways of R\&D capability building at emerging economy firms. Paper presented at The DRUID Society Conference, 16-18 June, CBS, Denmark.

Karabag, S.F., \& Berggren, C. (2014b). Antecedents of firm performance in emerging economies: Business groups, strategy, industry structure, and state support. Journal of Business Research, 67(10), 2212-2223.

Kazgan, G. (2004). Turkish Economy: From the Constitution of 1876 to 21 Century (in Turkish) (2nd ed.). Istanbul: IBU Publications.

Khanna, T., \& Rivkin, J.W. (2001). Estimating the performance effects of business groups in emerging markets. Strategic Management Journal, 22(1), 45-74.

Khanna, T., \& Yafeh, Y. (2005). Business groups and risk sharing around the world. The Journal of Business, 78(1), 301-340.

Kim, L. (1998). Crisis construction and organizational learning: Capability building in catching-up at Hyundai Motor. Organization science, 9(4), 506-521.

Kobrak, C., \& Schneider, A. (2011). Varieties of business history: Subject and methods for the twentyfirst century. Business History, 53(3), 401-424.

Kroeze, R., \& Keulen, S. (2013). Leading a multinational is history in practice: The use of invented traditions and narratives at AkzoNobel, Shell, Philips and ABN AMRO. Business History, 55(8), 1265-1287.

Ksoll, C., Macchiavello, R., \& Morjaria, A. (2014). Guns and Roses: Flower exports and electoral violence in Kenya. Working paper, http://cega.berkeley.edu/assets/miscellaneous_files/107__ABCA___MORJARIA_flowers_gnr.pdf Accessed 1 March 2018.

Küçükerman, Ö. (2008). Turkish Automotive Industry and the 40th year of Tofaş' 40th anniversary (1968-2008) (in Turkish). Istanbul: Tofaş Publication. 
Küçükahmetoğlu, O., Çeştepe, H., \& Tüylüoğlu Ş. (2000), Economic Integration: Global and Regional Perspective (in Turkish), Bursa: Ekin Yay.

Lall, S. (1992). Technological capabilities and industrialization. World Development, 20(2),165-186.

Lee, K. (2013). Capability failure and industrial policy to move beyond the middle-income trap: from trade-based to technology-based specialization. In J. E. Stiglitz, \& Y. J. Lin (Eds.), The Industrial Policy Revolution I: The Role of Government Beyond Ideology, (pp. 244-272). Palgrave Macmillan, London.

Luo, Y., \& Tung, R.L. (2007). International expansion of emerging market enterprises: A springboard perspective. Journal of International Business studies, 38(4), 481-498.

Leone, M.I., \& Reichstein, T. (2012). Licensing-in fosters rapid invention! The effect of the grantback clause and technological unfamiliarity. Strategic Management Journal, 33(8), 965-985.

Levinthal, D.A. (1991). Random walks and organizational mortality. Administrative Science Quarterly, 36(3), 397-420.

Maidique, M.A., \& Zirger, B.J. (1985). The new product learning cycle. Research Policy, 14(6), 299313.

Matthews, D. (2000). Oral history, accounting history and an interview with Sir John Grenside. Accounting, Business \& Financial History, 10(1), 57-83.

Maclean, M., Harvey, C., \& Stringfellow, L. (2017). Narrative, metaphor and the subjective understanding of historic identity transition. Business History, 59(8), 1218-1241.

McGovern, T. (2007). Why do successful companies fail? A case study of the decline of Dunlop. Business History, 49(6), 886-907.

Mellahi, K., \& Wilkinson, A. (2004). Organizational failure: a critique of recent research and a proposed integrative framework. International Journal of Management Reviews, 5(1), 21-41.

Mintzberg, H. (1978). Patterns in strategy formation. Management science, 24(9), 934-948.

Mintzberg, H., \& Waters, J.A. (1985). Of strategies, deliberate and emergent. Strategic Management Journal, 6(3), 257-272.

Nam, K.M. (2015). Compact organizational space and technological catch-up: Comparison of China's three leading automotive groups. Research Policy, 44(1), 258-272.

Onwuegbuzie, A.J., \& Leech, N.L. (2007). A call for qualitative power analyses. Quality \& Quantity, 41(1), 105-121.

Özatay, F. (2000). The 1994 currency crisis in Turkey. The Journal of Policy Reform, 3(4),327-352. 
Öniş, Z, \& Şenses, F. (2007). Global Dynamics, Domestic Coalitions and a Reactive State: Major Policy Shifts in Post-War Turkish Economic Development, Discussion Paper, Turkish Economic Association, No. 2007/7.

O’reilly, M., \& Parker, N. (2013). 'Unsatisfactory Saturation': a critical exploration of the notion of saturated sample sizes in qualitative research. Qualitative research, 13(2), 190-197.

Pamukçu, T. (2003). Trade liberalization and innovation decisions of firms: lessons from post-1980 Turkey. World Development, 31(8), 1443-1458.

Pamukçu, T., Sekkat, K., \& Taymaz, E. (2010). Entry, exit and productivity in Turkish manufacturing industries. In Sekkat, K. (Ed.), Market Dynamics and Productivity in Developing Countries (pp. 109143). New York: Springer.

Porter, M.E. (1990). The competitive advantage of nations. Harvard Business Review, 68(2), 73-93.

Porter, M.E. (1980). Competitive strategy: Techniques for analyzing industries and competitors. New York: Free Press.

Rafindadi, A.A., \& Yusof, Z. (2014). Are the periods of currency collapse an impediment to entrepreneurship and entrepreneurial haven? Evidence from regional comparison. International Journal of Economics and Financial Issues, 4(4), 886-908.

Robinson, O.C. (2014). Sampling in interview-based qualitative research: A theoretical and practical guide. Qualitative Research in Psychology, 11, 25-41.

Şenses, F. (2003). Economic Crisis as an Instigator of Distributional Conflict: The Turkish Case in 2001. Turkish Studies, 4(2), 92-119.

Sheppard, J.P., \& Chowdhury, S.D. (2005). Riding the wrong wave: Organizational failure as a failed turnaround. Long Range Planning, 38(3), 239-260.

Taymaz, E., \& Y1lmaz, K. (2014). Foreign ownership, survival and growth dynamics in Turkish manufacturing. In A. M. Ferragina, E. Taymaz, \& K. Yilmaz (Eds.), Innovation, Globalization and Firm Dynamics: Lessons for Enterprise Policy (pp. 237-264). New York: Routledge.

Thornhill, S., \& Amit, R. (2003). Learning about failure: Bankruptcy, firm age, and the resource-based view. Organization Science, 14(5), 497-509.

Tsai, K.H., \& Wang, J.C. (2007). Inward technology licensing and firm performance: a longitudinal study. $R \& D$ Management, 37(2), 151-160.

Tushman, M.L., \& Anderson, P. (1986). Technological discontinuities and organizational environments. Administrative Science Quarterly, 35(4), 439-465. 
Utterback, J.M., \& Suárez, F.F. (1993). Innovation, competition, and industry structure. Research Policy, 22(1), 1-21.

van de Ven, A.H. (1992). Suggestions for studying strategy process: A research note. Strategic Management Journal, 13(5), 169-188.

Vértesy, D. (2017). Preconditions, windows of opportunity and innovation strategies: Successive leadership changes in the regional jet industry. Research Policy, 46(2), 388-403.

Whetten, D.A. (1980). Organizational decline: A neglected topic in organizational science. Academy of Management Review, 5(4), 577-588.

Yamakawa, Y., Peng, M.W., \& Deeds, D.L. (2008). What drives new ventures to internationalize from emerging to developed economies?. Entrepreneurship Theory and Practice, 32(1), 59-82.

Yeldan, E. (2002). Behind the 2000/2001 Turkish Crisis: Stability, Credibility, and Governance, for Whom?, Ankara: BU Publications.

Zahra, S.A., Neubaum, D.O., \& Huse, M. (2000). Entrepreneurship in medium-size companies: Exploring the effects of ownership and governance systems. Journal of Management, 26(5), 947-976.

Zürcher, E. J. (2004). Turkey: A Modern History. New York: IB Tauris. 